\title{
Impact of a flipped classroom on academic achievement and perception among first year nursing students
}

\author{
Amal Amin El-Sheikh, Hanaa El-Sayed El-Sayad* \\ Surgical Nursing Department, Faculty of Nursing, Menoufia University, Egpty
}

Received: April 18, 2019

DOI: $10.5430 /$ cns.v7n3p68
Accepted: June 26, 2019

URL: https://doi.org/10.5430/cns.v7n3p68

\begin{abstract}
Background: Flipped classroom has generated significant concern in nursing education in recent years, particularly in higher education. It can provide an innovative solution to the unmet challenges of traditional classroom. Using video helps students to learn content at their own pace and use their time in the classroom to attack difficult problems. Aim of the study: to study the impact of a flipped classroom on academic achievement and perception among first year nursing students.

Methods: A quasi-experimental design was utilized. Setting: The study was conducted at Faculty of Nursing of Menoufia University. Subjects: A convenient sample of all first year undergraduate students (360) who were admitted to Faculty of Nursing and were included in fundamental of nursing course of the academic year 2017-2018 throughout second term. They were divided alternatively and randomly into two groups, 180 for each, group I: Exposed to the flipped classroom and group II: Exposed to the traditional lecture classroom. Tools: Three tools were used for data collection. Tool I: Structural interviewing questionnaire, tool II: student perception of flipped classroom and tool III: student achievement tool.

Results: The results revealed that the study group achieved higher level of perception towards flipped classroom after the first aid unit and the majority of them $(87.2 \%)$ did not have any prior experience of flipped classroom. 58.9\% of the study group were strongly agree to appreciate learning with video and about two thirds of them (63.9\%) strongly agree that it was easier and more effective to learn using flipped classroom. $65 \%$ of the study group were strongly agree that video made them learn more and about half of them $(57.2 \%)$ strongly agree that video could replace traditional lectures completely. The means total score of students' achievement were $22.22 \pm 5.09$ and $19.77 \pm 5.50$ among study and control group respectively.

Conclusions: Students shared in the flipped classroom (study group) achieved higher level of perception. The study group had higher level of achievement scores than those in the control group.

Recommendations: Similar studies should be carried out with a bigger sample in various courses and at various educational stages to generalize the findings.
\end{abstract}

Key Words: Flipped classroom, Academic achievement, Perception, First year nursing students

\section{INTRODUCTION}

Today, there is an increasing interest in using technology in order to improve teaching and learning methods in higher education. Selections of new teaching approaches are significant to be integrated into nursing education for improving the students' motivation and enhancing the learning process.

\footnotetext{
*Correspondence: Hanaa El-Sayed El-Sayad; Email: amal.elshikh@ hotmail.com; Address: Surgical Nursing Department, Faculty of Nursing, Menoufia University, Egpty.
} 
Inappropriate selection of teaching method can cause less learners interest. Current researches pays attention to active teaching methods for students in order to educate students and enhancing their creativity. ${ }^{[1,2]}$

One of the main components of successful teaching is flipped classroom also known as the inverted classroom or reversed instruction. It is an unconventional method that moves from conventional lectures to active learning and suggests chances to incorporate practices in classroom. With this method, students can access learning materials and complete a certain assignments a few days before the class meetings via a specific platform so that they will have plenty of time for practices and teacher feedback in face-to-face classes. ${ }^{[3]}$

Flipped classroom includes a reversal of the time and place for traditional lecture and homework, thus converting teaching and learning methods in several ways. In the flipped classroom educational approach, the traditional lecture is replaced by a system where learners watch video lectures before class and class time is used for active-learning activities such as small group exercises, application activities, case studies, discussions, return demonstration and role playing. This method involves the students energetically in course content throughout class occasion, so students are not passive recipients as happen in usual lectures. ${ }^{[4]}$

Students should watch videos before class time this is an essential element of flipped-classroom. Availability to these videos helps learners to manage the presentation of course content. Learners are capable of watching each video lecture at their chosen time and place; they may have flexibility as to when they connect with electronic resources, rewinding and quick-forwarding as needed. ${ }^{[5]}$ Flipped classroom involves changing teacher role to reduce quantity of direct teaching in their educational practice which permits extra teacherlearner interaction. To a certain extent instructor is being mainly a source of information, he acts as a facilitator $\&$ guide, feedback provider to learners, as a result instructor is capable of providing additional collaborative and cooperative involvement in his teaching process. ${ }^{[6]}$

Also flipped classroom helps students to be taught according to their own rate, motivates them to dynamically connect with teaching matter, frees up real class time for further useful, innovative and active learning practices. Instructors obtain prolonged opportunities to cooperate with and evaluate students' learning. Learners acquire management and dependability for their learning. Moreover this method may assist learners to progress self-efficacy through self studying, problem-solving and communication skills. ${ }^{[7]}$

Through flipped classroom students are able to regulate their

Published by Sciedu Press learning by incorporating their own life experiences into the classroom. Consequently, when students take ownership of their learning, the intrinsic perception of them in completing the required task can be achieved as well as they become academically motivated to do so which results in an increase in their self-efficacy. Students who exhibit higher levels of self-efficacy can formulate higher personal goals for their learning. ${ }^{[4]}$

There has been much enthusiasm surrounding flipped learning. The academic research on student perceptions of the flipped classroom suggests that general student opinion on this model tends to be constructive with an important minority being different. ${ }^{[7,8]}$

Numerous researches have been made to assess effect of flipped classroom on enhancement of student cognition and learning processes. Flipped learning has resulted in some improvement in course marks compared to non-flipped classes but this study is different. Study supposes that blended learning has potential to yield successful learning outcomes. Flipped classroom activities such as transfer of factual knowledge outside the classroom have helped to improve learning and engagement of students. ${ }^{[5]}$

Schwartz ${ }^{[9]}$ who applied flipped classroom in a statistics course in a nursing education Ph.D. program found that it is extremely successful in enhancing student learning. Also Bishop \& Verleger ${ }^{[10]}$ and Marlowe ${ }^{[11]}$ stated that flipped classroom has been used to improve levels of participation through integrating technology with student-centered learning.

\subsection{Significance of the study}

The researchers found a trouble of increasing students' numbers in Nursing Faculties in relation to number of nursing labs, and number of staff members during the education of fundamental of nursing course of the first year nursing students in adult health nursing department. This problem leads to decrease student-teacher interaction and return demonstration of the procedures. The researchers found an alternative method of traditional teaching which is known as flipped classroom. This method helps learners to build up a certain level of understanding of the taught material before presenting class and permits a greater time in class for problemsolving and clinical practice. It also generates more chances for the teacher to supply learners with direct formative feedback and cooperate with them in a more significant manner. Thus it helps learners to engage more actively with course material during class time. 


\subsection{Aim of the study}

To study the impact of a flipped classroom on academic achievement and perception among first year nursing students.

Hypotheses:

- Students of the study group (group 1) will experience a positive perception (high level of perception) toward flipped classroom.

- Students who participate in a flipped classroom will have higher achievement score than students who participate in traditional learning

\section{SUBJECTS AND METHODS}

2.1 Subjects

2.1.1 Research design

A quasi-experimental design was utilized.

\subsubsection{Setting}

The study was conducted at Faculty of Nursing Menoufia University.

\subsubsection{Subjects}

A convenience sample of all first year undergraduate nursing students (407) who were admitted to Faculty of Nursing and were included in fundamental of nursing course of the academic year 2017-2018 throughout second semester. They were divided alternatively and randomly into two equal groups, 180 for group 1 and 180 for group 2.

Group I: Exposed to the flipped classroom.

Group II: Exposed to the traditional lecture classroom.

The researchers were teaching two groups of the first aid unit and chose one to be flipped and the other to be traditional (see Figure 1).

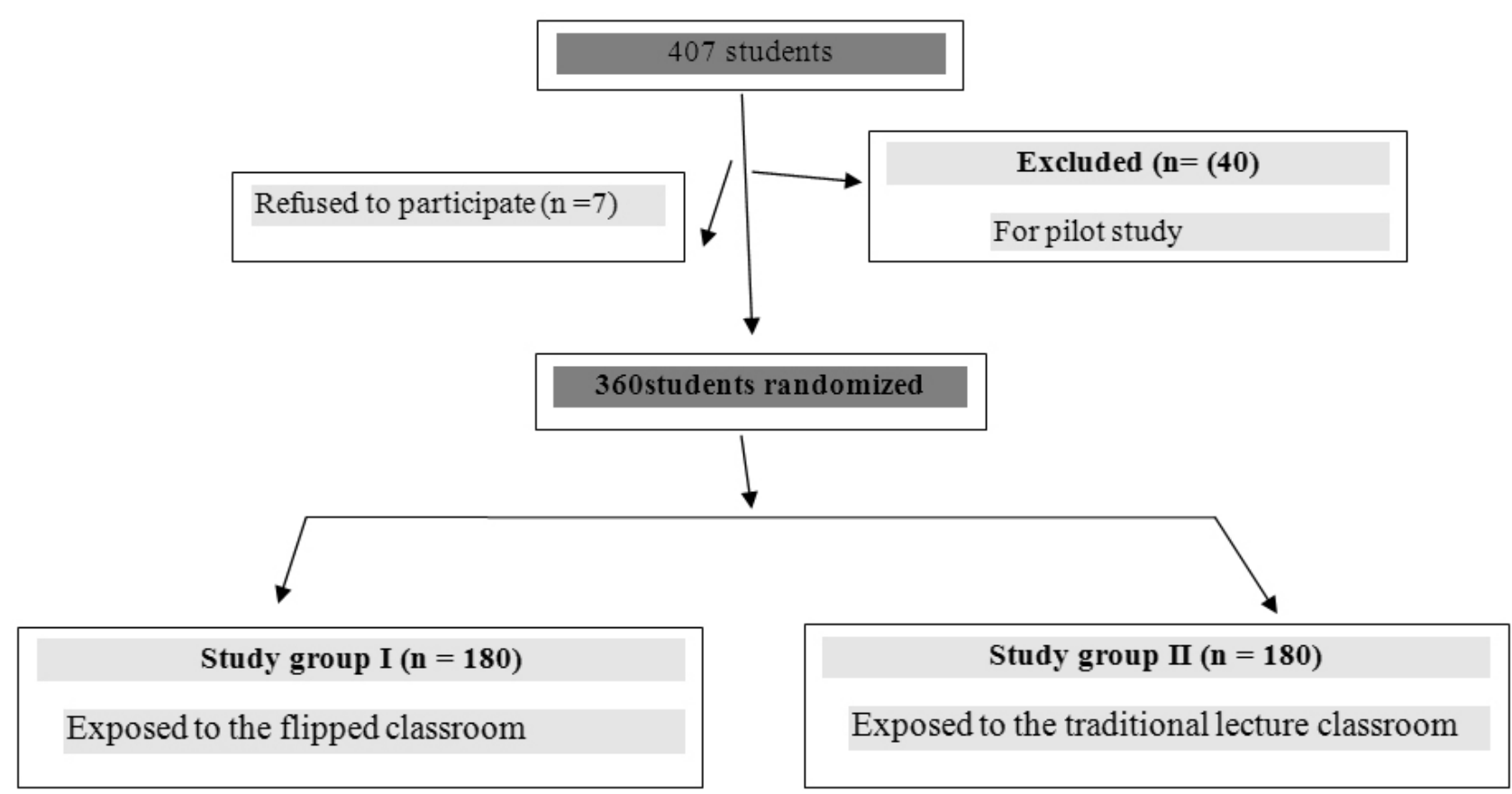

Figure 1. Subjects map

\subsubsection{Tools}

To achieve the aim of the study, three tools were developed and utilized by the researchers for data collection. These tools are as follow:

Tool I: Structural interviewing questionnaire: It was developed by researchers to assess basic students' personnel data such as: age and sex.

Tool II: Student perception: it was developed by Nouri. ${ }^{[12]}$ It consisted of 33 questions that included 3 parts:
- Part 1: Students' perception of flipped classroom after the first aid unit: to assess students' perception of learning through flipped classroom. It consisted of 17 questions regarding attitude toward flipped classroom, prior experience of flipped classroom, appreciation of learning, flexibility, responsibility for learning, studying pace, learning process, classroom activities, effectiveness of learning, studying in spare time, feeling of loneness, motivation, learner activation, learned amount, studying workload, peer collaboration and comparing flipped classroom with distance courses. Total 
score $=85$

- Part 2: Students' perception of using video for learning: to assess the student's perception of using video lectures as a medium for learning. It consisted of 12 questions regarding usefulness of pause, remind, fast forward, watching lecture in mobile way, combination of video and non traditional lecture, effectiveness of video, quality of video, ability to learn, motivation to learning, ability of video to replace traditional lecture, preference of video than traditional lecture and peer discussion. Total score $=60$.

- Part 3: Students' perception of using a circle discussion (conversation map): to assess the student's perception of using a circle discussion (conversation map). It consisted of 4 question regarding usefulness of seeing other students question, model support learning, communication with teacher and model motivation. Total score $=20$.

- Scoring system: Five point Likert-scale was used, the number of responses on item indicates the degree to which the respondents agree or disagree, it ranges from 1 (strongly disagree) to 5 (strongly agree). This questionnaire was estimated by the total number of responses by the participants, the higher the score mean the higher agreement. Total score $=165$.

Tool III: student achievement tool: it developed by the researchers to assess students' achievement score. It was consisted of 30 multiple choice questions that covered intended learning outcomes of the tough first aid lectures (shock, bleeding, fracture, cardiopulmonary resuscitation "CPR", poisoning and burn), each question answer was given score 1 if answer was correct and score 0 if answer was wrong. All scores were summed from total score of 30 .

\subsection{Method}

A written permission was obtained from head of the Medical Surgical Nursing Department of Menoufia Faculty of Nursing after explaining the aim of the study.

\subsubsection{Tools development}

The first and third tool were constructed by the researchers after reviewing the relevant literature. ${ }^{[7,8]}$ While the second tool was constructed by Nouri ${ }^{[12]}$ and all tools were tested for content validity by 5 experts specialized in Medical Surgical Nursing to ascertain relevance and completeness. Then these tools were tested for reliability by using a test- retest method and Pearson correlation coefficient formula was used. It was found to be 0.92 for tool one, 0.88 for the second tool and 0.89 for the third tool. Modifications were done accordingly to ascertain relevance and completeness.

Published by Sciedu Press

\subsubsection{Ethical consideration}

First year nursing students were included in the study, and then a clear and simple explanation about the nature and aims of the study was given to each participant. After that, a written consent was obtained from each participant to get his/her acceptance as well as cooperation. All participants were informed about confidentiality of the data and they have the right to withdraw from the study at any time without any effect on their learning.

Prior to the actual study, a pilot study was conducted on $10 \%$ of the study sample (40 students) to examine study tools for its precision, feasibility, applicability and establish the necessary time to complete theses tools after that essential modifications were carried out accordingly. Those who shared in the pilot study were excluded from the study sample.

\subsubsection{Data collections}

- Data were gathered over 6 weeks from the beginning of April to the half of May 2018.

- Students who agreed to participate in the study were randomly and alternatively divided into two groups.180 students for each group (I and II).

- Students of both groups were interviewed in their classroom to assess students' personnel data using tool I. It took about 15 minutes.

- Group 1 of flipped classroom (study group):

1. The researchers prepared six videos containing short lectures for teaching first aid unit (shock, bleeding, fracture, cardiopulmonary resuscitation "CPR", poisoning and burn). It takes about 30-45 minutes for each lecture. Six MS PowerPoint files were developed, each of these files focused on one lecture. To construct the videos, every one of these files was presented as a slide show and sound. Students were provided a $\mathrm{CD}$ or flash drive of the video contents.

2. All six videos were accessible to the participating students one week before the first lecture in the first aid unit. The unit had a total of 12 hours class time extend over a period of four weeks 3hours each week.

3. Students were asked to watch videos before class time, videos 1, 2 of shock\& bleeding before the first week of lecture, videos 3 of fracture before the second week, videos 4 of CPR before the third week and videos 5, 6 of poisoning \& burn before the fourth week and also read to the related topic in the course notes at home.

4. To encourage pre-class preparation, announced quizzes were given at the beginning of each class. These short, multiple-choice quizzes assessed basic understanding of the 
students.

5. The researchers divided group 1 into small 6 groups (30 students each), each group students engaged with researchers in a circle. The classes proceeded with active-learning exercises for the majority of the class period. Active-learning exercises included return demonstration, case studies, applying learning, guiding, problem-solving, analysis and discussions these were based on in-class outlines provided to students before the class.

6. the researchers recognized general misunderstandings or vague points among the students, and they supplied detailed explanations to the all students.

- Group II traditional classroom(control group):

1. Received the first aid lectures through traditional classroom. The unit had a total of 12 hours class time extend throughout a period of four weeks 3 hours each week.

2. Students Received the lecture of shock \& bleeding for the first week, fracture for the second week, CPR for the third week and poisoning \& burn for the fourth week.

3. Researchers were typically the central focus of a lesson and the primary disseminator of information during the class period. Class discussions are typically centered on the researchers, who controls the flow of the conversation.

- After the end of the first aid unit both study and control groups are given examination for these first aid lectures comprised of a multiple-choice question to evaluate students' achievement score (using tool III).
- Students of the study group were asked to complete the questionnaire to evaluate their perception about flipped classroom teaching (using tool II).

\subsubsection{Statistical analysis}

The data collected were tabulated \& analyzed by SPSS (statistical package for the social science software) statistical package version 20 on IBM compatible computer. Two types of statistics were done:

- Descriptive statistics: were expressed as mean and standard deviation $(X \pm S D)$ for quantitative data or number and percentage (No \& \%) for qualitative data.

- Analytic statistics: Chi-square test $\left(\chi^{2}\right)$ :It is the test of significance used to study association between two qualitative variables, $t$-test: is a test of significance used for comparison between two groups of normally distributed quantitative variables and Spearman correlation was used for quantitative variables that were not normally distributed or when one of the variables is qualitative-value at .05 was used to determine significance regarding-value $>.05$ to be statistically insignificant, $p$-value $\leq .05$ to be statistically significant and $p$-value $\leq .001$ to be highly statistically significant.

\section{RESULTS}

Table 1 shows that the mean age of study and control group was $18.95 \pm 0.37$ and $19.0 \pm 0.28$ years respectively. About two thirds of study group $(61.7 \%)$ and about half of control group $(53.3 \%)$ were female. There were no statistical significant differences between both groups (study and control) regarding demographic characteristics.

Table 1. Distributions of demographic characteristics of the studied groups

\begin{tabular}{|c|c|c|c|c|c|c|}
\hline \multirow{2}{*}{$\begin{array}{l}\text { Socio-demographic } \\
\text { characteristics }\end{array}$} & \multicolumn{2}{|c|}{ Study group $(\mathrm{n}=180)$} & \multicolumn{2}{|c|}{ Control group $(\mathbf{n}=180)$} & \multirow{2}{*}{$\begin{array}{c}\text { Test of } \\
\text { significance }\end{array}$} & \multirow{2}{*}{$p$-value } \\
\hline & No. & $\%$ & No. & $\%$ & & \\
\hline \multicolumn{7}{|l|}{ Age (years): } \\
\hline Mean $\pm S D$ & \multicolumn{2}{|c|}{$18.95 \pm 0.37$} & \multicolumn{2}{|c|}{$19.0 \pm 0.28$} & \multirow{2}{*}{$t$-test $=1.40$} & 0.16 \\
\hline Range & & & & & & NS \\
\hline \multicolumn{7}{|l|}{ Gender: } \\
\hline Male & 69 & 38.3 & 84 & 46.7 & \multirow{2}{*}{$\chi^{2}=2.55$} & 0.11 \\
\hline Female & 111 & 61.7 & 96 & 53.3 & & NS \\
\hline
\end{tabular}

Note. $t=$ student's $t$ test; $\chi^{2}=$ Chi square test; $S D=$ standard deviation; NS = non-significant $(p$-value $>.05)$

Table 2 reveals that more than two thirds of them $(87.2 \%)$ did not have a prior experience of flipped classroom. More than half of the study group $(58.9 \%)$ was strongly agree to appreciate learning with video and about two thirds of them $(63.9 \%)$ was strongly agree that it was easier and more effective to learn using flipped classroom. The mean total score of study group was $66.39 \pm 11.28$ regarding students' perceptions of flipped classroom after the first aid unit. 
Table 2. Distributions of students' perceptions of flipped classroom

\begin{tabular}{|c|c|c|c|c|c|c|}
\hline Items & $\begin{array}{l}\text { Strongly } \\
\text { disagree } \\
\mathbf{N}(\%)\end{array}$ & $\begin{array}{l}\text { Disagree } \\
\mathbf{N}(\%)\end{array}$ & $\begin{array}{l}\text { Neutral } \\
\mathbf{N}(\%)\end{array}$ & $\begin{array}{l}\text { Agree } \\
\text { N }(\%)\end{array}$ & $\begin{array}{l}\text { Strongly agree } \\
\mathbf{N}(\%)\end{array}$ & Mean $\pm S D$ \\
\hline \multicolumn{7}{|l|}{ 1. I have a prior experience of flipped classroom } \\
\hline Yes N $(\%)$ & $23(12.8)$ & & & & & $1.12 \pm 0.33$ \\
\hline No $N(\%)$ & $157(87.2)$ & & & & & \\
\hline $\begin{array}{l}\text { 2. I have a positive attitude towards flipped } \\
\text { classroom after the unit }\end{array}$ & $0(0.0)$ & $0(0.0)$ & $38(21.1)$ & $31(17.2)$ & $111(61.7)$ & $4.40 \pm 0.81$ \\
\hline 3. I appreciate learning with video & $0(0.0)$ & $11(6.1)$ & $29(16.1)$ & $34(18.9)$ & $106(58.9)$ & $4.30 \pm 0.95$ \\
\hline 4. I am more flexible and mobile as learner & $0(0.0)$ & $8(4.4)$ & $8(4.4)$ & $53(29.4)$ & $111(61.7)$ & $4.48 \pm 0.78$ \\
\hline 5. I have to take more responsibility for learning & $0(0.0)$ & $1(0.6)$ & $11(6.1)$ & $69(38.3)$ & $99(55.0)$ & $4.47 \pm 0.63$ \\
\hline 6. I can study in my own pace & $0(0.0)$ & $11(6.1)$ & $9(5.0)$ & $49(27.2)$ & $111(61.7)$ & $4.44 \pm 0.84$ \\
\hline 7. My learning processes are more supported & $0(0.0)$ & $10(5.6)$ & $18(10.0)$ & $47(26.1)$ & $105(58.3)$ & $4.37 \pm 0.87$ \\
\hline $\begin{array}{l}\text { 8. The non-traditional classroom activities were } \\
\text { meaningful }\end{array}$ & $0(0.0)$ & $20(11.1)$ & $20(11.1)$ & $50(27.8)$ & $90(50.0)$ & $4.16 \pm 1.01$ \\
\hline 9. It is easier and more effective to learn & $0(0.0)$ & $29(16.1)$ & $1(0.6)$ & $35(19.4)$ & $115(63.9)$ & $4.31 \pm 1.09$ \\
\hline $\begin{array}{l}\text { 10. I do more studying/learning on my own spare } \\
\text { time }\end{array}$ & $10(5.6)$ & $18(10.0)$ & $12(6.7)$ & $39(21.7)$ & $101(56.1)$ & $4.12 \pm 1.23$ \\
\hline 11. I feel more alone & $8(4.4)$ & $11(6.1)$ & $17(9.4)$ & $43(23.9)$ & $101(56.1)$ & $4.21 \pm 1.12$ \\
\hline 12. I am more motivated as learner & $0(0.0)$ & $11(6.1)$ & $17(9.4)$ & $39(21.7)$ & $113(62.8)$ & $4.41 \pm 0.89$ \\
\hline 13. I am more active as a learner & $0(0.0)$ & $0(0.0)$ & $38(21.1)$ & $31(17.2)$ & $111(61.7)$ & $4.40 \pm 0.81$ \\
\hline 14. I learn more & $0(0.0)$ & $0(0.0)$ & $32(17.8)$ & $52(28.9)$ & $96(53.3)$ & $4.35 \pm 0.76$ \\
\hline 15. I feel an increased workload that is stressful & $80(44.4)$ & $20(11.1)$ & $42(23.3)$ & $32(17.8)$ & $6(3.3)$ & $2.24 \pm 1.27$ \\
\hline 16. I experience stronger peer. collaboration & $0(0.0)$ & $9(5.0)$ & $40(22.2)$ & $50(27.8)$ & $81(45.0)$ & $4.12 \pm 0.92$ \\
\hline 17. It feels like a distance course & $0(0.0)$ & $0(0.0)$ & $32(17.8)$ & $36(20.0)$ & $112(62.2)$ & $4.44 \pm 0.77$ \\
\hline Total score & & & & & & $66.39 \pm 11.28$ \\
\hline
\end{tabular}

Table 3. Distributions of students' perceptions of using video for learning

\begin{tabular}{|c|c|c|c|c|c|c|}
\hline Items & $\begin{array}{l}\text { Strongly } \\
\text { disagree } \\
\mathrm{N}(\%)\end{array}$ & $\begin{array}{l}\text { Disagree } \\
\mathbf{N}(\%)\end{array}$ & $\begin{array}{l}\text { Neutral } \\
\mathbf{N}(\%)\end{array}$ & $\begin{array}{l}\text { Agree } \\
\mathbf{N}(\%)\end{array}$ & $\begin{array}{l}\text { Strongly } \\
\text { agree } \\
\mathrm{N}(\%)\end{array}$ & Mean $\pm S D$ \\
\hline 1. Useful to pause video. & $0(0.0)$ & $0(0.0)$ & $32(17.8)$ & $26(14.4)$ & $122(67.8)$ & $4.50 \pm 0.78$ \\
\hline 2. Useful to rewind video & $0(0.0)$ & $1(0.6)$ & $11(6.1)$ & $40(22.2)$ & $128(71.1)$ & $4.63 \pm 0.62$ \\
\hline 3. Useful to fast forward video & $0(0.0)$ & $1(0.6)$ & $33(18.3)$ & $32(17.8)$ & $114(63.3)$ & $4.43 \pm 0.80$ \\
\hline 4. Useful to watch lectures in a mobile way & $0(0.0)$ & $10(5.6)$ & $20(11.1)$ & $75(41.7)$ & $75(41.7)$ & $4.19 \pm 0.84$ \\
\hline $\begin{array}{l}\text { 5. The combination of video and non-traditional } \\
\text { lectures was useful }\end{array}$ & $0(0.0)$ & $1(0.6)$ & $11(6.1)$ & $66(36.7)$ & $102(56.7)$ & $4.49 \pm 0.63$ \\
\hline 6. Video made learning more effective & $0(0.0)$ & $0(0.0)$ & $12(6.7)$ & $81(45.0)$ & $87(48.3)$ & $4.41 \pm 0.61$ \\
\hline 7. Video quality was satisfactory & $0(0.0)$ & $1(0.6)$ & $13(7.2)$ & $100(55.6)$ & $66(36.7)$ & $4.28 \pm 0.61$ \\
\hline 8. Video made me learn more & $0(0.0)$ & $9(5.0)$ & $8(4.4)$ & $46(25.6)$ & $117(65.0)$ & $4.50 \pm 0.80$ \\
\hline 9. Video motivated me to learn & $0(0.0)$ & $10(5.6)$ & $7(3.9)$ & $73(40.6)$ & $90(50.0)$ & $4.35 \pm 0.80$ \\
\hline $\begin{array}{l}\text { 10. Video can replace traditional lectures } \\
\text { completely }\end{array}$ & $0(0.0)$ & $1(0.6)$ & $28(15.6)$ & $48(26.7)$ & $103(57.2)$ & $4.40 \pm 0.76$ \\
\hline 11. I rather have traditional lectures than video & $40(22.2)$ & $56(31.1)$ & $51(28.3)$ & $33(18.3)$ & $0(0.0)$ & $2.42 \pm 1.03$ \\
\hline $\begin{array}{l}\text { 12. Learning through video resulted in more peer } \\
\text { discussions }\end{array}$ & $0(0.0)$ & $17(9.4)$ & $49(27.2)$ & $69(38.3)$ & $45(25.0)$ & $3.78 \pm 0.92$ \\
\hline Total score & & & & & & $50.44 \pm 5.73$ \\
\hline
\end{tabular}


Table 3 presents that about two thirds of the study group $(65 \%)$ was strongly agree that video made them learn more and about half of them $(57.2 \%)$ was strongly agree that video can replace traditional lectures completely. In relation to Students' perceptions of using video for learning, the mean total score of study group was $50.44 \pm 5.73$.

Table 4 demonstrates that more than half $(59.4 \%)$ of the study group was strongly agree that it was useful to communicate with teachers through circle discussion and $48.9 \%$ of them strongly agree that circle discussion supported their learning.

Table 4. Distributions of students' perceptions of using circle discussion (conversation map)

\begin{tabular}{|c|c|c|c|c|c|c|}
\hline Items & $\begin{array}{l}\text { Strongly } \\
\text { disagree } \\
\mathbf{N}(\%)\end{array}$ & $\begin{array}{l}\text { Disagree } \\
\mathbf{N}(\%)\end{array}$ & $\begin{array}{l}\text { Neutral } \\
\mathbf{N}(\%)\end{array}$ & $\begin{array}{l}\text { Agree } \\
\mathbf{N}(\%)\end{array}$ & $\begin{array}{l}\text { Strongly } \\
\text { agree } \\
\mathbf{N}(\%)\end{array}$ & Mean $\pm S D$ \\
\hline $\begin{array}{l}\text { 1. It was useful to see other students questions and } \\
\text { teacher answers in circle discussion }\end{array}$ & $0(0.0)$ & $11(6.1)$ & 25 (13.9) & $65(36.1)$ & 79 (43.9) & $4.17 \pm 0.89$ \\
\hline 2. circle discussion supported my learning & $0(0.0)$ & $10(5.6)$ & 37 (20.6) & $45(25.0)$ & $88(48.9)$ & $4.17 \pm 0.94$ \\
\hline $\begin{array}{l}\text { 3. It was useful to communicate with teachers } \\
\text { through circle discussion }\end{array}$ & $0(0.0)$ & $0(0.0)$ & $33(18.3)$ & $40(22.2)$ & $107(59.4)$ & $4.41 \pm 0.78$ \\
\hline 4. circle discussion motivated me to learn & $0(0.0)$ & $0(0.0)$ & $33(18.3)$ & $60(33.3)$ & $87(48.3)$ & $4.30 \pm 0.76$ \\
\hline Total score & & & & & & $17.06 \pm 3.06$ \\
\hline
\end{tabular}

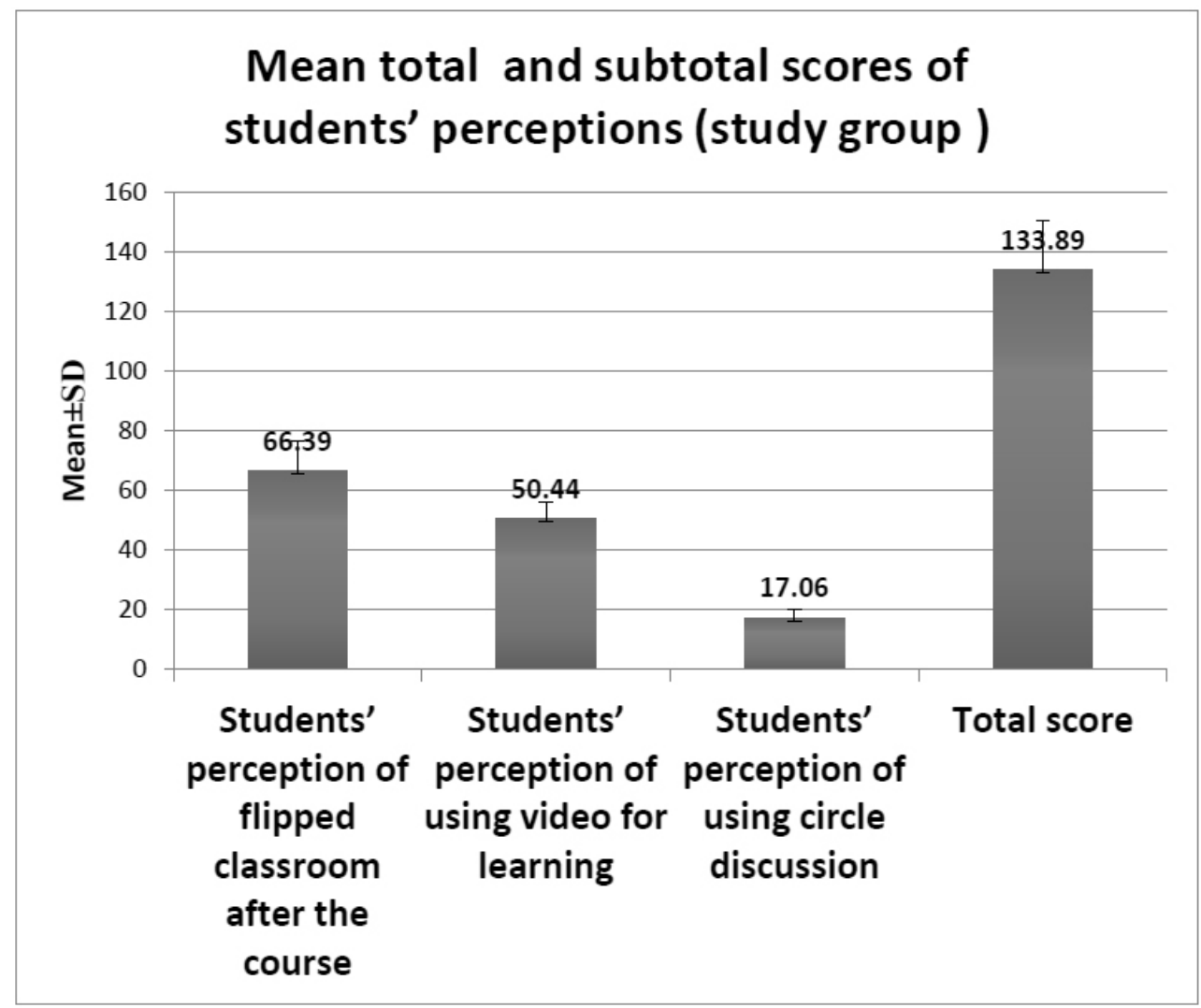

Figure 2. Mean total and subtotal score of students' perceptions (study group)

Figure 2 shows the mean score of study group perceptions regarding Students' perceptions of flipped classroom after the first aid unit, Students' perceptions of using video for learning and Students' perceptions of using circle discussion were $66.39 \pm 11.28,50.44 \pm 5.73$ and $17.06 \pm 3.06$ respectively. As regards to total score students' perceptions of the study group, the mean total score was $133.89 \pm 20.07$.

Figure 3 reveals the mean total score of students' achieve- 
ment was $22.22 \pm 5.09$ and $19.77 \pm 5.50$ among study and icant differences between students of both groups regarding control group respectively. There were high statistical signif- mean total score of students' achievement ( $p$-value $\leq .001)$.

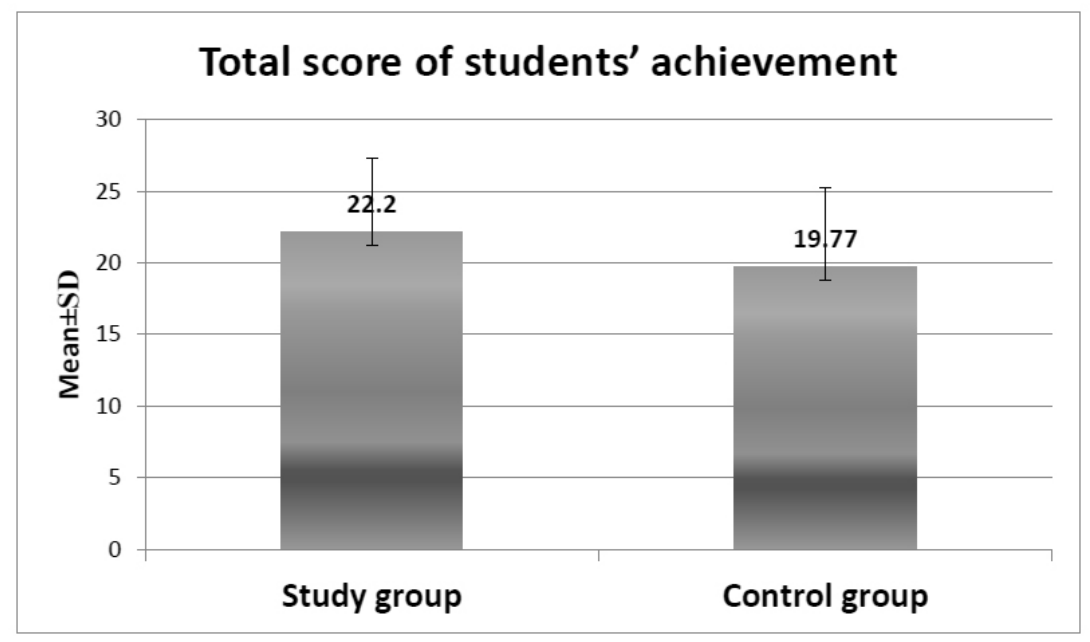

Figure 3. Correlation between total score of students' achievement \& total score of students' perceptions among study group

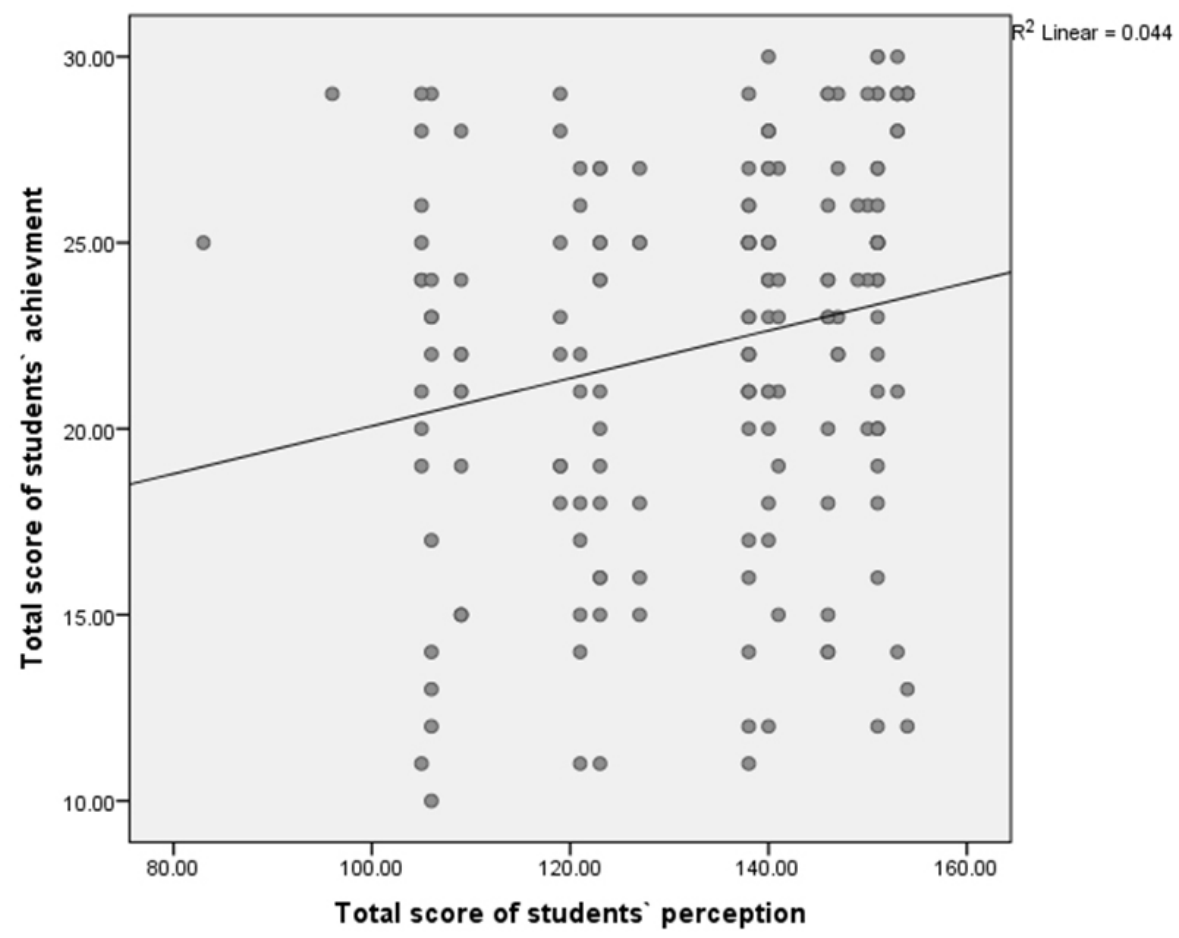

Figure 4. Correlation between total score of students' achievement \& total score of students' perceptions among study group

Figure 4 reveals that there were significant positive correlations between total score of students' achievement \& total score of students' perceptions among study group $(r=0.24$ and $p$-value .001).
Table 5 illustrates there was no relation between demographic characteristics of the studied groups \& their achievement score ( $p$-value of study group was .57 for age and .51 for gender) \& ( $p$-value of control group was .99 for age and .54 for gender). 
Table 5. Relation between demographic characteristics of the study and control groups \& their total achievement score

\begin{tabular}{|c|c|c|c|c|}
\hline \multirow[t]{2}{*}{ Demographic characteristics } & $\begin{array}{l}\text { Study group } \\
\quad(\mathbf{n}=\mathbf{1 8 0})\end{array}$ & $\begin{array}{c}\text { Control group } \\
(\mathbf{n}=\mathbf{1 8 0})\end{array}$ & \multirow{2}{*}{$\begin{array}{c}\text { Test of } \\
\text { significance }\end{array}$} & \multirow[t]{2}{*}{$p$-value } \\
\hline & Mean $\pm S D$ & Mean $\pm S D$ & & \\
\hline Age (years): & $r=-0.04$ & $r=0.001$ & Spearmans' rho & $\begin{array}{l}.57^{*} \mathrm{NS} \\
.99 \mathrm{NS}\end{array}$ \\
\hline \multicolumn{5}{|l|}{ Gender: } \\
\hline Male & $22.53 \pm 4.55$ & $20.04 \pm 5.09$ & $t=0.65^{*}$ & $.51^{*} \mathrm{NS}$ \\
\hline Female & $22.02 \pm 5.42$ & $19.54 \pm 5.86$ & $t=0.61$ & $.54 \mathrm{NS}$ \\
\hline
\end{tabular}

Note. ${ }^{*}$ study group

Table 6. Relation between demographic characteristics of the study group \& their total perceptions score

\begin{tabular}{|c|c|c|c|}
\hline \multirow[t]{2}{*}{ Socio-demographic characteristics } & $\begin{array}{l}\text { Study group } \\
\quad(n=180)\end{array}$ & \multirow[t]{2}{*}{ Test of significance } & \multirow[t]{2}{*}{$p$-value } \\
\hline & Mean $\pm S D$ & & \\
\hline Age (years): & $r=-0.14$ & Spearmans' rho & $.06 \mathrm{NS}$ \\
\hline \multicolumn{4}{|l|}{ Gender: } \\
\hline Male & $133.71 \pm 14.23$ & \multirow{2}{*}{$t=0.14$} & \multirow{2}{*}{$.88 \mathrm{NS}$} \\
\hline Female & $133.36 \pm 18.07$ & & \\
\hline
\end{tabular}

Table 6 shows there was no relation between demographic characteristics of the study group \& their perceptions score ( $p$-value .06).

\section{Discussion}

The Flipped Classroom (FC) is an instructional approach which supplies educators by mean of diminishing the quantity of direct-instruction in their education practice whereas optimizing conversation interface. Recently, the flipped classroom has produced significant attention in nursing higher education.

The current study revealed that mean age of subjects of in the present study was about nineteen years. In contrast to this result Yacout and Abou Shosha illustrated that the majority of sample were above 20 years. ${ }^{[13]}$ This contradiction may be attributed to that the researchers in current study select to study the first year undergraduate students only.

Regarding sex, the finding of the current study illustrated that more than half of the sample was females. This result was in line with Kurtz, et al., who stated the majority of the sample were females ${ }^{[14]}$ and also in line with Yacout and Abou Shosha who stated that less than three quarters of studied students were female. ${ }^{[13]}$

The results of current study demonstrated that the majority of flipped classroom participants had not any experience with FC. Furthermore most of them had high perceptions towards flipped classroom after the unit. The rationale for this was that participants enjoyed learning through video material that give them the chance to learn in their own speed, flexibility and mobility conveyed by available video lectures and that learning is effortless and more successful within the structure of the flipped classroom. The results were in line with Yacout and Abou Shosha who stated majority of learners affirmed that FC is an innovative practice for them. Furthermore, majority of them had highly perceptions regarding FC learning approach. ${ }^{[13]}$

About two thirds of the study group was strongly agree that video made them learn more and about half of them strongly agree that video could replace traditional lectures completely. The videos helped them to watch the lectures, replay videos to recognize indistinguishable parts of videos lecture for further discussion. Also the videos helped them acquire knowledge and prepare for in-class, active-learning activities. The findings of current study agreed with Mikkelsen stated that more than quarters of his studied students believed that the videos were better than traditional lectures with regard to learning outcome. ${ }^{[15]}$ Moreover Veeramani et al., revealed that FC allowed a greater understanding of the topic, a larger interest, motivation to actively connect with the subject before the class, as advantages to FC. ${ }^{[16]}$ While in disagreement with Misseldine et al., illustrated that nursing students who had involved in a flipped-classroom course were dissatisfied with using video in FC. This may be recognized that combination new education approach with interactive classroom activities as flipped classroom can produce better learning 
but not essentially enhanced learners' satisfaction. Moreover, this may be owing to learners were unwilling to perform the additional effort necessary to get ready before class if they do not perceive the benefit of doing it or have a lot of homework to be arranged. ${ }^{[17]}$

The current research demonstrated that more than half of the flipped classroom students strongly agree that it was useful to communicate with teachers through circle discussion and near half of them strongly agree that circle discussion supported their learning. In the line with these results Shi-Chun indicated most of students mentioned FC encourage discussion with their peer and support their learning. ${ }^{[18]}$ Moreover Kecskemety had reported that discussion through the flipped classroom approach making the learners dependable for their learning and helping them build up lifelong learning and communication skills. ${ }^{[19]}$

As regard total score of students' achievement, it was noted from the current study that the mean total score of students' achievement was $22.22 \pm 5.09$ of the study group and 19.77 \pm 5.50 of the control group. This was in line with Zengin who found that the FC learning environment doubled the learners' educational achievement. Moreover, this learning method enhanced students' learning, allowed visualization in mathematics teaching, and donated life-long learning. ${ }^{[20]}$ Also Janotha studied effect of FC teaching on the academic achievement of nursing students. The students in the study group taught trough FC Model and control groups taught through traditional method, it was found the students in the study group achieved higher academic performance than the students in the control group. ${ }^{[21]}$ In addition Zhonggen and Wang illustrated the subjects who were taught using the FC Model scored higher than those in control group who were taught in a traditional manner ${ }^{[22]}$ Our study illustrated that flipped teaching could considered a precious way for enhancing academic achievement on shorter time applications.

Conversely Geist et al., and Harrington et al., found that there were no differences in the final exam scores between students undertaking traditional lectures and those in the flipped classroom. ${ }^{[23,24]}$ Also Cabi carried out a study to study the impacts of the FC Model on students' academic achievements; the findings showed there were no statistically significant differences between both groups and the FC Model does not provide an important impacts on improving the students' academic achievement. ${ }^{[25]}$

The results of present study indicated there was no association between demographic characteristics of the study group and there positive perceptions regarding flipping classroom strategy. In agreement this finding Davey found that there were no significant relations between his subjects' general characteristics and FC strategy. ${ }^{[26]}$ While Yacout and Abou Shosha contradicted these findings and illustrated that there were significant differences between students' general characteristics as age, gender, residence and last academic achievements and there constructive perceptions regarding flipping classroom strategy. ${ }^{[13]}$

It was noticed from the study that there were significant positive correlations between total score of students' achievement \& total score of students' experiences among study group. This is in agreement with Nouri who stated the majority of the students had a positive attitude towards flipped classroom, the use of video and model. This positive attitude towards flipped classroom was strongly associated with increased motivation, engagement, and effective learning. ${ }^{[12]}$

\section{Conclusions}

Findings of the current study concluded that the flipped classroom was an important teaching approach in nursing education that can produce a high level of both perception and academic achievement among study group. Students in the study group had higher academic achievement than students in the control group and there were significant positive correlations between total score of students' achievement \& total score of students' perception among study group.

\subsection{Recommendations}

Based on the findings of this study:

1. Similar studies should be carried out with a bigger sample in different courses and at different levels of education to generalize the findings.

2. Develop high quality videos like embedded quizzes, and activities to generate an additional engaging experience for the students.

\section{CONFLICTS OF INTEREST DisClOSURE}

The authors declare they have no conflicts of interest. 


\section{REFERENCES}

[1] Clark KR. Flipping Out: A Trend in Radiological Science Education. Radiologic Technology. 2014; 85(6): 685-687.

[2] Eichler J, Peeples J. Flipped classroom modules for large enrollment general chemistry courses: A low barrier approach to increase active learning and improve student grades. Chemistry Education Research and Practice. 2016; 17(1): 197-208. https://doi.org/10.1039/ C5RP00159E

[3] Hung H. Flipping the classroom for English language learners to foster active learning. Computer Assisted Language Learning. 2015 28(1): 81-96. https://doi.org/10.1080/09588221.2014.96 7701

[4] Smallhorn M. The flipped classroom: A learning model to increase student engagement not academic achievement. Student Success. 2017; 8(2): 43-53. https://doi.org/10.5204/ssj .v8i2. 381

[5] Chen HL, Chang CY. Integrating the SOP2 model into the flipped classroom to foster cognitive presence and learning achievements. Educational Technology \& Society. 2017; 20(1): 274-291.

[6] Jerri L, Deal B, Hermanns M. Implementation of a Flipped Classroom: Nursing students perspective. Journal of Nursing Education and Practice. 2015; 5(6): 25-30. https ://doi.org/10.5430/jn ep. v5n6p25

[7] Gilboy MB, Heinerichs S, Pazzaglia G. Enhancing student engagement using the flipped classroom. Journal of Nutrition and Educational Behavior. 2015; 47(1): 109-114. PMid: 25262529. https://doi.org/10.1016/j.jneb.2014.08.008

[8] Halili SH, Zainuddin Z. Flipping the classroom: What we know and what we don't. The Online Journal of Distance Education and e-Learning. 2015; 3(1): 15-22.

[9] Schwartz TA. Flipping the Statistics Classroom in Nursing Education. Journal of Nursing Education. 2014; 53(4): 199-206. PMid: 24654591. https://doi.org/10.3928/01484834-201 40325-02

[10] Bishop JL, Verleger MA. The flipped classroom: A survey of the research. In ASEE National Conference Proceedings, Atlanta, GA. 2013; 30(9).

[11] Marlowe CA. The effect of the flipped classroom on student achievement and stress. (Master's Thesis), Montana State University, Bozeman, MT. 2012.

[12] Marlowe CA. The effect of the flipped classroom on student achievement and stress. Master's Thesis. Montana State University, Bozeman, MT. 2012. https : //doi .org/10.1186/s41239-016-0032-z

[13] Yacout D, Shosha A. Nursing Students' Perceptions Towards Flipped Classroom Educational Strategy. J Am Sci. 2016; 12(2): 62-75.

[14] Kurtz G, Tsimerman A, Steiner-Lavi O. The flipped-classroom approach: The answer to future learning? European Journal of Open,
Distance and E-learning. 2014; 17(2): 172-82. https : //doi .org/ 10.2478/eurodl-2014-0027

[15] Mikkelsen T. Nursing students experiences, perceptions and behavior in a flipped-classroom anatomy and physiology course. Journal of Nursing Education and Practice. 2015; 5(10): 28-30. https: //doi.org/10.5430/jnep.v5n10p28

[16] Veeramani R, Venkatesh S, Madhugiri CP. Perception of MBBS students to "flipped class room" approach in neuroanatomy module. Anat Cell Biol. 2015; 48: 138-143. PMid: 26140225. https : //doi.org/10.5115/acb.2015.48.2.138

[17] Misseldine K, Fountain R, Summers L. Flipping the Classroom to Improve Student Performance and Satisfaction. Journal of Nursing Education. 2013; 52(10): 597-599. PMid: 24044386. https: //doi.org/10.3928/01484834-20130919-03

[18] Du SC, Fu ZT, Wang Y. The Flipped Classroom-Advantages and Challenges. International Conference on Economic Management and Trade Cooperation. 2014; 17-20.

[19] Kecskemety K. Student Perceptions of Inverted Classroom Benefits in a First-Year Engineering Course Ohio State University. American Society for Engineering Education. 2014. Available from: wWw. asee.org

[20] Zengin Y. Investigating the use of the Khan Academy and mathematics software with a flipped classroom approach in mathematics teaching. Journal of Educational Technology \& Society. 2017; 20(2): 89-100.

[21] Janotha B. Improving student achievement with flipped classroom pedagogy. Nursing Research. 2016; 65(2): 100-101.

[22] Zhonggen Y, Wang G. Academic achievements and satisfaction of the clicker-aided flipped business English writing class. Journal of Educational Technology \& Society. 2016; 19(2): 298.

[23] Geist MJ, Larimore D, Rawiszer H, et al. Flipped versus traditional instruction and achievement in a baccalaureate nursing pharmacology course. Nurs Educ Perspect. 2015; 36: 114-115. PMid: 29194136. https://doi.org/10.5480/13-1292

[24] Harrington SA, Bosch MV, Schoofs N, et al. Quantitative outcomes for nursing students in a flipped classroom. Nurs Educ Perspect. 2015; 36: 179-181. https://doi.org/10.5480/13-1255

[25] Cabi E. The Impact of the Flipped Classroom Model on Students' Academic Achievement. International Review of Research in Open and Distributed Learning. 2018. https://doi.org/10.19173/i rrodl.v19i3.3482

[26] Davey P. The Flipped Classroom: Motivating Student Nurses to Learn Independently. Athens: ATINER'S Conference Paper Series, No: NUR 2015-1594. 2015. https://doi.org/10.30958/ajh . 2-4-2 